\title{
The Positions of The Host Country Agreement in Industrial Relations Dispute Cases Under Indonesian Law (ASEAN Foundation Case)
}

\author{
Sri Gilang Muhammad Sultan Rahma Putra \\ \{srigilangmsrp@gmail.com\} \\ Research and Development Center for Law and Judiciary, Jalan Jend. Ahmad Yani Kav. 58 bypass \\ Cempaka Putih Jakarta Pusat
}

\begin{abstract}
The ASEAN Foundation Industrial Relations Dispute Case at the Supreme Court of the Republic of Indonesia caused a polemic. The position of the agreement between the host country and international organizations when dealing with Indonesian labor law creates differences of opinion among legal experts. This research tries to look at the ASEAN Foundation case from a balanced perspective between international law and the protection of basic workers' rights in international organizations. This research is a normative legal research with a case approach and a statutory approach. This research aims to provide answers on how courts should decide similar cases in the future.
\end{abstract}

Keywords: ASEAN Foundations, Host Country Agreement, Indonesian Law

\section{Introduction}

Work is one of the ways that every human being takes to make ends meet. Because work activities are so important in fulfilling the needs of human life, the guarantee of a decent job and livelihood has earned a place as a right guaranteed in the constitution of the Republic of Indonesia. In the current era of globalization where boundaries between countries are increasingly fading and also encourages increased international interaction between various countries. One of the consequences of this era of globalization is the emergence of crosscountry workers, namely people who work outside of their country.

The era of globalization and increased international cooperation also encourages the growth of various international organizations. This international organization generally aims to be a place of international cooperation. Another consequence of the existence of international organizations is the existence of workers from various countries who work for international organizations. A simple employment relationship can be understood as a relationship between workers and employers. A relationship that occurs between two or more parties always has the potential to cause conflict, as well as a work relationship between an employee and an employer. Labor disputes or also known as industrial relations disputes are one of the special cases in civil courts in the general court environment.

Industrial relations disputes do not only occur within the scope of work that is local in nature. However, this is the consequence of globalization which allows one to work across countries. The existence of transnational workers has also opened up the potential for 
industrial relations disputes that are cross-country in nature. This transnational dispute over industrial relations generally occurs in multinational companies.

In connection with the presence of international organizations that have consequences for the existence of workers from various countries working in these international organizations, the potential for cross-border industrial relations disputes also has the potential to emerge from international organizations. In this article, industrial relations disputes that occur between workers and international organizations are related to cases between the ASEAN Foundation and one of its workers. International organizations as they are known to have existed in international relations and are one of the legal subjects that are recognized as subjects of international law.

In connection with the operations of an international organization, generally an international organization has a secretariat which is the administrative operational center of the international organization. The secretariat or headquarters of an international organization usually stands in a country that was agreed upon when the international organization was founded. In connection with the existence of a secretariat or headquarters of this international organization in a country, generally as an international law subject that has rights and obligations based on international law.

In general, between international organizations and the country where the secretariat of the international organization is established, they enter into an agreement known as the host country agreement. This host country agreement generally regulates the rights and obligations between the host country and the international organization, as well as in general about the immunity of the international organization.

Industrial relations dispute cases discussed in this paper are cases between employees of the ASEAN Foundation and the ASEAN Foundation, which is part of the ASEAN International Organization which has a central secretariat based in Jakarta. In connection with this case which is the topic of this research, the problem to be discussed in this study is what is the position of the host country agreement in Indonesian national law? The issue regarding the position of the host country agreement in this case is important to answer because if you refer to the ASEAN Foundation case decision document, it will be seen that the matter of the host country agreement is one of the legal arguments used by one of the parties, namely the ASEAN Faoundation and by other parties. asked to be considered by the judge. However, in his decision the judge adheres to and refers to the national law, not the host country agreement. Therefore, according to the researcher, it is important to know about the position of the host country agreement in the Indonesian national legal system in order to deal with similar cases in the future so that there is a clear guideline and provide legal certainty.

\section{Research Methods}

The method used in this research is a normative legal research method. The normative legal research method is research that examines positive law from its normative perspective. The normative legal research method is a unique method in legal science. These distinctive characteristics arise from the character of law science which is a sui generis science [1]. Normative legal research needs to be carried out in order to overcome the problem of norm conflicts, norm voidness or norm obscurity [2]. The final objective of a normative legal research is to produce a prescription in order to overcome the identified legal problem or issue [3]. This normative legal research uses primary legal materials and secondary legal materials 
as a source of research data [3]. The primary legal materials used in this research are court decisions regarding industrial relations disputes related to the ASEAN Foundation, namely the Supreme Court Cassation Decision Number: 1100 K / Pdt.Sus-PHI / 2016 and the Supreme Court Reconsideration Decision Number: 14 PK / Pdt. Sus-PHI / 2019. Apart from these various decisions, the primary legal material used in this research is in the form of laws and regulations related to the settlement of industrial relations disputes. Because this research is related to international law, the primary legal materials used also include sources of international law.

The primary legal materials in this research that come from international legal sources include international conventions related to international treaties and also international agreements between international legal subjects and international organizations. Secondary legal materials used in this research are various written publications that discuss the problem of the relationship between international law and national law, regarding industrial relations disputes and international organization law, especially some relevant previous research results and other written publications in the field of law relevant to needs this research.

The approach used in this legal research is the statute approach and the case approach. The statutory approach in this study will be used to analyse or understand the ratio legislation of legislation and international treaties which are the primary legal materials in this study. The case approach, in this study, is used to analyse the decidendi ratio in court decisions with industrial relations disputes in international organizations which are used as primary legal materials in this study. According to Johny Ibrahim [4], the case approach in normative legal research aims to study the application of legal norms or rules that are carried out in legal practice. In this research, the aim is to study how legal norms regulating the relationship between international law and national law and international organization law as well as industrial relations disputes are applied in legal practice, namely through judges' decisions.

\section{Results and Discussion}

The relationship between international law and national law is one of the important topics in various studies of international law. In the current era of globalization when the boundaries between countries are getting thinner in their various activities, this also has the consequence of the increasing role of international law. In this case, it refers to Lung Chu Chen's view that positions international law, in this case international treaties, as a joint policy option with the international community to solve a problem or achieve certain goals.[5].

By referring to Lung Chu Chen's view, the attitude taken by a country regarding the issue of the relationship between international law and national law is important. This is because even though a policy has been chosen by the international community, the implementation of international policy choices that have been agreed upon through an international agreement is very much dependent on how international law is accepted in the national legal system of each country that has agreed in the international agreement.

Clarity regarding the relationship between national law and international law in the national legal system of a country is important, especially in this case for the judiciary. For the judiciary, clarity regarding the status of the relationship between national law and international law can become a reference for courts when it comes to deciding cases that have a point of contact with national law. 
In the context of the relationship between international law and national law, research conducted by Damos Dumoli Agusman found that Indonesia has not provided a clear position in its constitution regarding the position of international law in Indonesian national law whether it adheres to monism or dualism.[6] Meanwhile, in terms of practice, still citing a study conducted by Damos Dumoli Agusman, it turns out that there are variations in the practice of applying international law to national law, namely sometimes adhering to monism and sometimes adhering to dualism.[6]

In addition to citing the views as the results of the study by Damos Dumoli Agusman, the judiciary, in this case through the Spokesperson of the Supreme Court, has also conveyed views regarding the problem of the relationship between national law and international law that there needs to be a legal basis for judges regarding the use of international legal instruments such as resolutions UNSC, this is because it is related to the legality principle adhered to in Indonesian law.[7]

The two statements previously made clearly show that in the Indonesian national legal system there is no clarity regarding the relationship between national law and international law. This situation has triggered variations in practice in judicial decisions as found in research conducted by Simon Butt which states that Indonesian practices show a tendency towards dualism, but in several decisions of the Supreme Court and the Constitutional Court it shows the application of monism.[8]

The Indonesian judiciary, in this case the Supreme Court, has quite often received and decided cases that have a point of contact with international law. Cases that have a point of contact with international law are generally related to several spheres of cases, including arbitration issues, diplomatic immunity issues and industrial relations disputes and other matters.

Cases related to industrial relations disputes that have a point of contact with international law have occurred several times in recent years. These cases include disputes over industrial relations between local staff workers and representatives of foreign countries in Indonesia. The Supreme Court responded to the existence of industrial relations dispute cases involving representatives of foreign countries in Indonesia by issuing Supreme Court Circular Letter Number 4 of 2016 which provides instructions that the court has the authority to hear industrial relations dispute cases between local staff workers and representatives of foreign countries.

However, it is different from industrial relations dispute cases involving representatives of foreign countries, industrial relations dispute cases involving the ASEAN Foundation which are the topic of this research have different characteristics from industrial relations dispute cases involving representatives of foreign countries. The distinctive characteristics of this ASEAN Foundation case include, first, this case involves an international organization. In international law, international organizations are separate legal subjects that are different from other international legal subjects.

Second, this case involves several legal regimes in the law of international organizations, international treaty law and national labor law. Third, in contrast to representatives of foreign countries whose immunity is regulated in international conventions, international organizations, especially those related to the secretariat of the organization regarding immunity, are regulated in more detail in an agreement between the international organization and the host country where the secretariat of the international organization is domiciled. The agreement between the international organization and the host country is known as the host country agreement. Therefore, it is important to see how the Indonesian court views the position of this host country agreement. 
The ASEAN Foundation case decision document reviewed in this study consists of two decision documents, namely the decision at the cassation level with the decision number: 1100 K / Pdt.Sus-PHI / 2016 and the decision at the level of reconsideration with decision number: 14 PK / Pdt.Sus -PHI / 2019.

This research will focus on the study of the cassation level decision document. The decision document at the review level is not the focus of the study, because the decision at the review level contains unacceptable case decisions, so it is only related to formal aspects and does not raise any arguments regarding material matters related to the position of the host country agreement. Referring to the section on the consideration of the panel of judges in the decision document number: $1100 \mathrm{~K} / \mathrm{Pdt}$.Sus-PHI / 2016, it is found that the important points of consideration of the panel of judges are as follows:

1) Host country agreement between Indonesia and ASEAN secretariat is public agreement

2) Contract of employment is a private agreement

3) Public agreements may not waiver the employment contract

4) There are the cases of the ASEAN foundation subject to Indonesian labor laws

Referring to the main points of the panel of judges' arguments, it can be seen that if the judges know and pay attention to the existence of a host country agreement between Indonesia and the ASEAN Secretariat, however, the panel of judges is of the opinion that the host country agreement is not related to the issue of work contract disputed in an industrial relations dispute. this. In the view of the panel of judges, these two matters fall within the scope of different laws, thus the work contract issue in this case is subject to Indonesian labor law.

Regarding the attitude of the judiciary in cases that have a point of contact with international law, it is necessary to pay attention to the research of David L. Sloss and Michael P. van Alstine which divides court attitudes into two forms of attitude, namely using the harmonization technique and the avoidance technique.[9]

Harmonization technique means that the courts apply international law by harmonizing national law with international law.[9] Avoidance technique means the court does not apply international law and applies national law to decide the cases being handled.[9]

If it is related to David L. Sloss' research, it can be concluded that in this ASEAN Foundation case, the court applied the avoidance technique in its decision. Regarding the position of the host country agreement, this decision shows that the host country agreement cannot deviate from national law in industrial relations disputes, but this decision does not explain the position of the host country agreement in the Indonesian national legal system.

Judicial practice in this decision has shown that international organizations in matters of industrial relations disputes cannot hide behind immunity as stipulated in the host country agreement and courts have jurisdiction in adjudicating work contract cases at international organizations.

\section{Conclusion}

Based on the preliminary studies that have been carried out in this research as described in the previous sections of this paper, the conclusions of this preliminary study can be conveyed as follows: First, in terms of the relationship between national law and international law, the Indonesian court in the decision This ASEAN Foundation case uses avoidance techniques. The avoidance technique in this case means the court decides cases based on national law and 
does not use or refer to the relevant international law. The second conclusion from this preliminary study is that based on the decision of this case, it can be concluded that in the Indonesian legal system, agreements between the host country and international organizations cannot violate Indonesian national law.

\section{Acknowledgements}

I would like thanks to Lengga and Siwi for their support and discussion in the preparation of this article.

\section{References}

[1] P. M. Hadjon and T. S. Djatmiati, Argumentasi Hukum. Jogjakarta: Gajah Mada University Press, 2005.

[2] I. M. P. Diantha, Metodologi Penelitian Hukum Normatif dalam Justifikasi Teori Hukum. Jakarta: Kencana Prenada Media Group, 2016.

[3] P. M. Marzuki, Penelitian Hukum, Revisi. Jakarta: Kencana Prenada Media Group, 2014

[4] J. Ibrahim, Teori \& Metodologi Penelitian Hukum Normatif. Malang: Bayumedia, 2007.

[5] L. C. Chen, An Introduction to Contemporary International Law (A Policy Oriented Perspective), Second. New York: Yale University Press, 2000.

[6] D. D. Agusman, Treaties Under Indonesia Law (A Comparative Study). Bandung: Rosda International, 2014

[7] N. E. Elnizar, "Juru Bicara MA: Hakim bisa Gunakan Resolusi DK PBB di Peradilan, Asalkan...," 2018. https://www.hukumonline.com/berita/baca/lt5b5827d5d7d08/juru-bicara-ma--hakim-bisagunakan-resolusi-dk-pbb-di-peradilan--asalkan (accessed May 29, 2019).

[8] S. Butt, "The Position of International Law Within the Indonesian Legal System," Emory Int. Law Rev., vol. 28, no. 1, pp. 1-28, 2014.

[9] D. L. Sloss and M. P. Van Alstine, "International Law in Domestic Courts," in Research Handbook on The Politics of International Law, W. Sandholtz and C. A. Whytock, Eds. Cheltenham UK: Edward Elgar Publishing, 2017, pp. 79-115. 